\title{
SNRPF Gene
}

National Cancer Institute

\section{Source}

National Cancer Institute. SNRPF Gene. NCI Thesaurus. Code C29960.

This gene plays a role in nuclear mRNA splicing. 